\title{
Review
}

\section{Walter Benjamin's antifascist education: from riddles to radio}

Tyson E. Lewis,

State University of New York Press, Albany, 2020,

$250 \mathrm{pp}$.,

ISBN: 978-1438477510

Contemporary Political Theory (2022) 21, S154-S158. https://doi.org/10.1057/s41296021-00507-8; published online 28 July 2021

Walter Benjamin's long-standing concern with learning, education, and teaching is manifest in many of his texts. As a student of the educational reformer Gustav Wyneken and an active member of the German youth movement, Benjamin's early writings from 1911 to 1922 are marked by an idealistic invoking of 'Youth's awakening', a critique of the educational system, and a plea for 'knowledge for knowledge's sake'. These early texts contain, in essence, ideas that Benjamin will develop in his later writings, such as the link between education and the radical transformation of society. While from 1915 onward, 'youth' was no longer the locus of Benjamin's engagement with education and learning, these themes reappear in his preoccupation with the world of children, children's books, and toys. They are taken up in numerous texts and reviews between 1928 and 1932, as well as in his late engagement with proletarian pedagogy. At the core of Benjamin's thoughts on education and pedagogy lies the idea of teaching, not as the transmission of knowledge, but as a 'thinking-together' of student, teacher, and the object of knowledge through different media that makes teaching, understood in this way, transmissible. Whether a theory or philosophy of education can be extracted from Benjamin's oeuvre has always been debated. Any attempt to systematize such a theory would have to account for Benjamin's critique of theory production in general, and academic theory in particular. As such, a systematic attempt to articulate Benjamin's philosophy of pedagogy would yield a pedagogy of anti-pedagogy.

Recent years have seen a renewed interest in Benjamin's thinking on education and pedagogy, which is in large part due to new English translations of his early writings (Benjamin, 2011). While Benjamin's works directly addressing learning and education have received critical attention, however the thread on education and learning that runs through other, less prominent texts is yet to be fully explored. 
In Walter Benjamin's antifascist education, Tyson E. Lewis takes up this task. Lewis traces Benjamin's thoughts on education through various texts, media and cultural practices 'as a dispersal of educational themes outward, beyond the schoolhouse and the university into public forms of pedagogy, including radio and children's theater and ... into informal educational forms such as collecting, wandering the city, [or] laughing at film' (Lewis, 2021, p. 113). Walter Benjamin's antifascist education is, then, an attempt to provide a comprehensive analysis of educational themes across the entirety of the critical theorist's diverse writings.

The book is organized in two parts: while the first is concerned with 'strong' educational forms such as radio broadcasts and children's theater, the latter introduces us to 'weaker' or marginalized ones like cityscapes, word games, and collections. While the former 'prolong and stretch out learning, giving it duration (through pedagogical tactics, organizing, and script writing, respectively)' (p. 114), the latter present only momentary, fleeting forms of study. Central to this 'constellational curriculum' (p. 19) are thresholds, particularly threshold-acts and threshold-figures that Lewis maps out, reinforcing his argument that no single educational form (figure or act) is adequate to the task of an education as a whole. Lewis thus turns Benjamin's constellational thinking back on Benjamin's own work, framing his project as an 'imaginative (de)formation' (p. 31) of Benjamin's thought, rather than a summary of fragments, remnants, and traces on learning and education in his work.

This constellational engagement with Benjamin's theory is methodologically worth supporting, as it not only takes Benjamin's fragmentary thinking and writing seriously, but also provides the reader with links and relations that might be missed in a solely genealogical or historical reading. Yet even though Lewis claims to use Benjamin's early engagement with education only as a point of departure, he nevertheless appropriates a vocabulary that is particularly reminiscent of Benjamin's youthful writing: the language of swelling, of waves crashing, or of the spilling of truth that carry the weight of Benjamin's early metaphysical writings, which he himself abandons in his later work in favor of a more radicalized notion of education mediated through technology.

This rather metaphorical 'understanding of education as a specific kind of swelling' (Lewis, 2021, p. 113) at times brushes over the mediacy of Benjamin's idea of education - a mediacy Lewis himself, however, alludes to throughout the book: at the core of Benjamin's thought on education and pedagogy lies the idea of teaching not as exemplifying knowledge but as the quest for transmissibility. This makes education a mode of relating to a technologically mediated environment and thus a concrete historico-political project without an identifiable essence.

Here I want to focus on Lewis' description of Benjamin's pedagogical project as antifascist. Despite its noble aims, Lewis' notion of the 'protofascistic [authoritarian] personality', defined in terms of 'hardness, coldness, and manipulativeness' 
(p. 131), is an essentializing figure that reduces antifascism to a solely reactive movement against fascist tendencies.

In contrast to Adorno's theories of the authoritarian character, Benjamin's understanding of fascism emerges at the intersection of body and society, between individual psychology and social totality (pp. 5-16). This, in Lewis' terms, 'embodied' understanding of fascism makes it possible to connect the subjective and objective dimensions of lived experience. Benjamin's approach is defined then as 'much more focused on the body, bodily practices, perception, and a new notion of a diasporic connectivity to others (human and nonhuman) as they emerge within yet against the barbarism of fascism' (p. 16). The crux of Benjamin's thought on education is its unwieldiness that cannot be fully grasped through thinking: the 'primal experiences' at work in education 'cannot be disrupted or dislodged through critical reasoning alone' (p. 17). The idea of an autonomous, critically selfaware subject is constantly (and productively) undermined in Benjamin's thinking of an 'embodied' education. Lewis reads this tendency as a call for a new fullbodied politics 'that heightens and expands receptive senses as well as new practices that generate 'alter-shocks' to an already shocking system' (p. 16) What makes Benjamin's thought on education so fascinating for our current times, then, is its commitment to working within rather than against forms of affective communication: 'If fascism, at its base, is an attempt to keep asleep, lost in a dream, then Benjamin's antifascist education concerns bodily and affective awakenings to potentialities for other forms of life from within yet against this very dreamscape' (p. 23).

Against fascist hardness, Lewis positions mimesis and its capacity to entangle the body with others through augmentation. Against coldness, which 'freezes' capacity and capability, he positions innervation as exaggeration, which disrupts sedimented habits. And against manipulation and control, he positions distraction as the suspension of will and the yielding to experience. Lewis pointedly draws on 'fascism's grip on the body and its affective pull' (p. 16), but fails to consider Benjamin's complex, original, and decisively political distinction between a body (Leib) and corporeal substance (Körper). This distinction informs his understanding of an 'embodied' education: sensory affection, innervation, pleasure, laughter, and pain are not only related to the individual's 'corporeal substance' (Körper), but this 'corporeal substance' is itself related to the collective body, or bodily collective, 'which is both agent and object of the human interaction with nature ... Technology endows the collective with a new physis that demands to be understood and re/appropriated, literally incorporated, in the interest of the collective; at the same time, technology provides the medium in which such reappropriation can and must take place' (Hansen, 2004, p. 17). The decidedly political, antifascist education we can derive from Benjamin's writing, then, is not concerned with quantitatively amassing individual Körper but with the production, emergence, and potential of a qualitatively new collective body. 
Lewis alludes to such a notion of collectivity, but he understands it as a property ('collective formations', 'collective energies', a 'collectively full life') rather than as a political concept in its own right. Only in relation to fascism is the collective defined, in Lewis' terms, 'by clear boundaries that limit the powers of mimetic semblance to the closest things rather than the most remote' (p. 107). Despite Lewis's recognition that the 'fascist' is not a prototype but the (mediated) 'survival' of authoritarianism among the white middle class, he later regresses into an idealtypical image of the fascist personality, body, and collective - as illustrated by references to British Holocaust denier David Irving and the debunked 'conversations' between Joseph Goebbels and Hermann Rauschning, who provide him with the clearest examples of the prototypical fascist (pp. 10, 205).

The potential of an investigation into 'education', and specifically 'antifascist education', as a matter of liminal experiences and potentialities, is incredibly promising, insofar as the fascist (or authoritarian) character is here thought of as a possible emergence and a potential figure inherent to bourgeois and capitalist society. But unfortunately, Lewis' analogies fall flat in light of the (re-)emergence of contemporary fascism(s) worldwide. His attachment to the prototypical fascist body beyond its technological mediation fails to consider what Simon Strick describes as 'reflexive fascism', which draws heavily on affective economies beyond communication. As Strick argues, 'reflexive fascism ... occupies the gestures and signatures of those politics that have formed against the institutionalized annihilation projects of fascism and colonialism: identity politics, antihegemony, the political and manifest representation of minorities, and also antifascism' (Strick, 2021, p. 114; my translation). The decisive antifascist potential inherent in Benjamin's ideas on education stems from his attention to mediacy, transmissibility, and its relation to technologies. Despite the somewhat narrow condensation of these relationalities into the metaphor of 'swelling', Lewis's book provides a rich source of educational forms and figures in Benjamin's writings that speak to their need for actualization.

\section{Funding}

Open Access funding enabled and organized by Projekt DEAL.

\section{Open Access}

This article is licensed under a Creative Commons Attribution 4.0 International License, which permits use, sharing, adaptation, distribution and reproduction in any medium or format, as long as you give appropriate credit to the original author(s) and the source, provide a link to the Creative Commons licence, and indicate if changes were made. The images or other third party material in this article are included in the article's Creative Commons licence, unless indicated 
otherwise in a credit line to the material. If material is not included in the article's Creative Commons licence and your intended use is not permitted by statutory regulation or exceeds the permitted use, you will need to obtain permission directly from the copyright holder. To view a copy of this licence, visit http:// creativecommons.org/licenses/by/4.0/.

\section{References}

Benjamin, W. (2011) Early Writings (1910-1917). Edited by Howard Eiland. Cambridge: Belknap Press. Hansen, M. (2004) Room-for-Play: Benjamin's Gamble with Cinema. October 109 (2004): 3-45.

Lewis, T. (2021) In Defense of Walter Benjamin's Constellational Curriculum: A Response to the Critics. Studies in Philosophy and Education 40(1): 113-116. https://doi.org/10.1007/s11217-02009747-4.

Strick, S. (2021) Rechte Gefühle. Affekte und Strategien des digitalen Faschismus. Bielefeld: transcript Verlag.

Publisher's Note Springer Nature remains neutral with regard to jurisdictional claims in published maps and institutional affiliations.

Caroline Adler

Humboldt-University Berlin, 10117 Berlin, Germany caroline.adler@hu-berlin.de 